\title{
Transposición congénitamente corregida de grandes arterias en mujer adulta: aporte en imágenes de la resonancia nuclear magnética
}

\section{Transposition of the great vessels congenitally corrected in an adult woman: usefullness of cardiac resonance images}

\author{
Javier López Pais*, Juan Gorriz Magaña y Jesús Saavedra Falero
}

Servicio de Cardiología. Hospital Universitario de Getafe. Getafe, Madrid, España

\section{PALABRAS CLAVE}

Cardiopatías congénitas del adulto;

Resonancia magnética nuclear;

Ecocardiografía

\section{KEYWORDS}

Congenital heart disease in adults;

Magnetic resonance imaging;

Echocardiography

La levo transposición de los grandes vasos es una infrecuente forma de cardiopatía congénita (el $0,2 \%$ de los nacidos con cardiopatías congénitas), caracterizada por una discordancia aurículo-ventricular y ventrículo-arterial. Si se presenta aislada se trata de una anomalía fisiológicamente corregida, no siendo cianógena, ya que la sangre sistémica desoxigenada llega a la circulación pulmonar y la oxigenada

\footnotetext{
* Autor para correspondencia.

Correo electrónico: javierlopezpais@gmail.com (J. López Pais).
}

fluye a la sistémica. Los pacientes pueden llevar una vida normal hasta la edad adulta.

Valoramos por alteraciones electrocardiográficas inespecíficas (fig. 1) a una mujer de 41 años de edad, sin antecedentes conocidos y con buena clase funcional. El ecocardiograma hizo sospechar una levo transposición de los grandes vasos. Se le realizó resonancia cardiaca en la que reconocemos el ventrículo anatómicamente izquierdo por su morfología cónica (fig. 2-VI), en él drena la aurícula derecha, que recibe el retorno venoso sistémico. Dicho ventrículo presenta unos espesores parietales disminuidos, ya

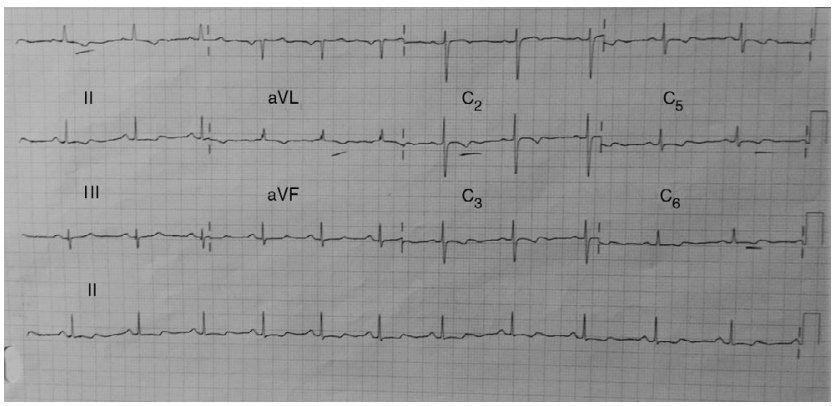

Figura 1 Electrocardiograma que muestra alteraciones difusas en la repolarización, lo que motivó el resto de estudios. 


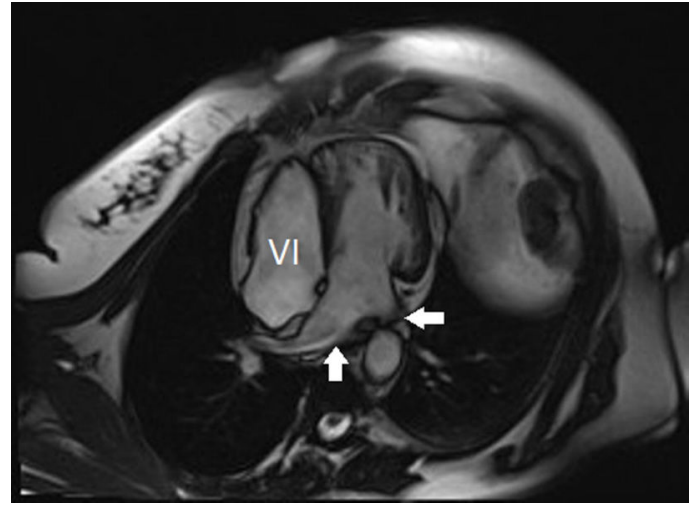

Figura 2 Imagen axial de resonancia que permite visualizar las 4 cámaras cardiacas y sus relaciones. vi: ventrículo izquierdo. Flechas: venas pulmonares.

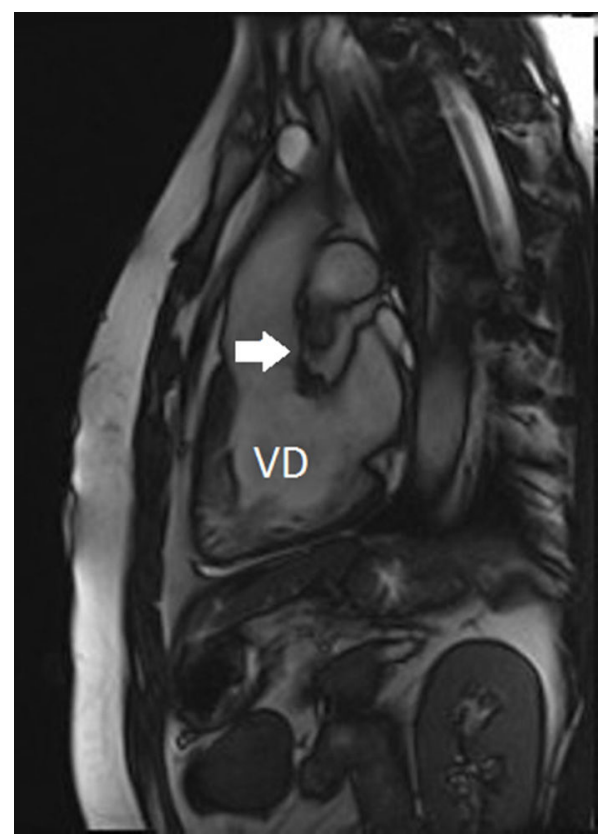

Figura 3 Imagen sagital de resonancia centrada en el ventrículo sistémico y sus relaciones.VD: ventrículo derecho. Flecha: infundíbulo muscular. que genera presiones de la circulación pulmonar, y está desplazado por la gran masa del ventrículo sistémico. Se visualiza con detalle un ventrículo anatómicamente derecho (fig. 3-VD) que cumple con los requerimientos sistémicos a expensas de la hipertrofia. A él, a través de la válvula tricúspide, drena la aurícula izquierda, que recibe las venas pulmonares (fig. 2 - flechas). Se observa el componente muscular del infundíbulo que soporta la válvula aórtica, lo cual es usual en esta patología (fig. 3 - flecha].

La historia natural es que en la cuarta década de la vida el ventrículo sistémico empiece a claudicar, dado que nuestra paciente permanece asintomática, continuaremos con revisiones y de ser necesario, se planteará para trasplante, ya que en adultos es la mejor alternativa que disponemos.

\section{Conflicto de intereses}

Todos los autores declaran que no existe ningún conflicto de interés. 